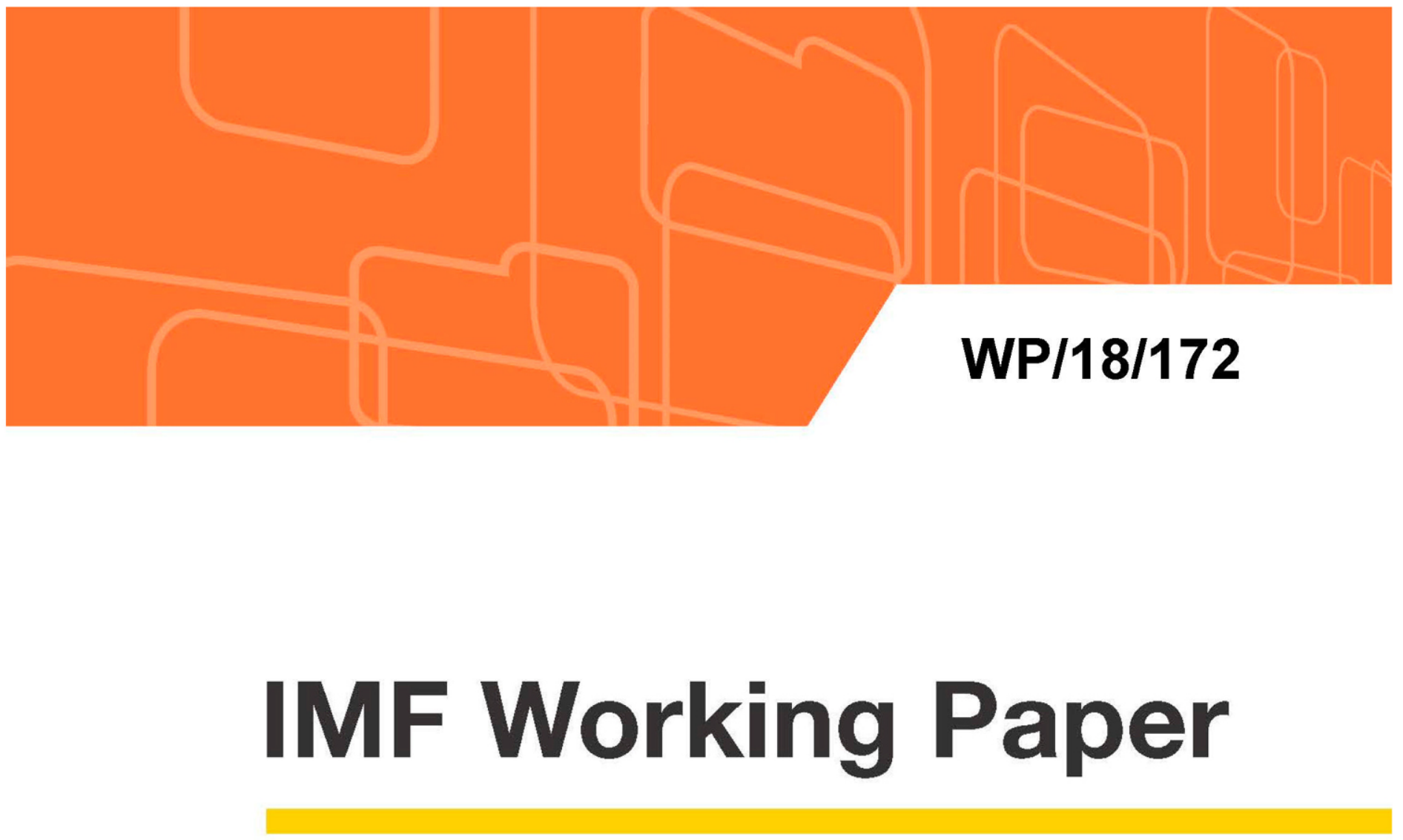

\title{
Demographics and Interest Rates in Asia
}

by Serkan Arslanalp, Jaewoo Lee and Umang Rawat

IMF Working Papers describe research in progress by the author(s) and are published to elicit comments and to encourage debate. The views expressed in IMF Working Papers are those of the author(s) and do not necessarily represent the views of the IMF, its Executive Board, or IMF management. 


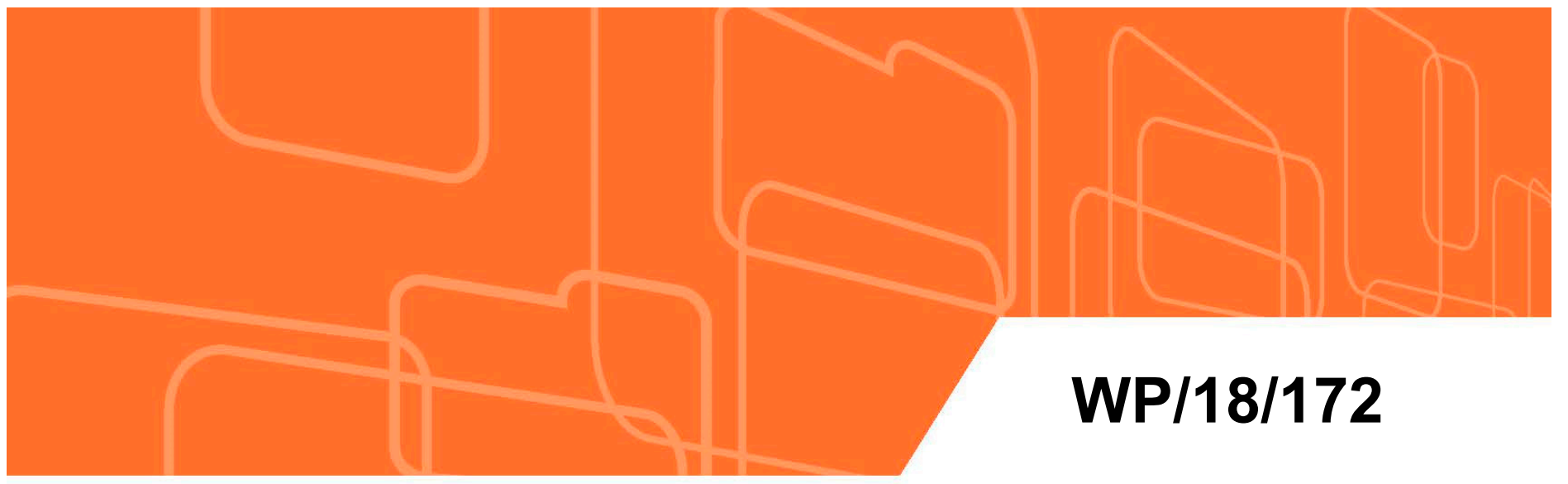

\section{IMF Working Paper}

\section{Demographics and Interest Rates in Asia}

by Serkan Arslanalp, Jaewoo Lee and Umang Rawat

IMF Working Papers describe research in progress by the author(s) and are published to elicit comments and to encourage debate. The views expressed in IMF Working Papers are those of the author(s) and do not necessarily represent the views of the IMF, its Executive Board, or IMF management. 


\title{
IMF Working Paper
}

Asia and Pacific Department

\section{Demographics and Interest Rates in Asia}

Prepared by Serkan Arslanalp, Jaewoo Lee, and Umang Rawat ${ }^{1}$

Authorized for distribution by Ranil M. Salgado

July 2018

\section{IMF Working Papers describe research in progress by the author(s) and are published to elicit comments and to encourage debate. The views expressed in IMF Working Papers are those of the author(s) and do not necessarily represent the views of the IMF, its Executive Board, or IMF management.}

\begin{abstract}
Demographic developments have been regarded as one important cause of the long-term movement in global interest rates. This paper provides empirical evidence of the relationship between demographics and interest rates over a wide sample of advanced and emerging market economies. It also finds that capital account openness limits the direct sensitivity of a country's interest rates to its own demographics. The results suggest that future demographic developments will continue to apply downward pressure on the interest rates in Asia which foresees a rapid aging.
\end{abstract}

JEL Classification Numbers: E2, F3, J1

Keywords: demographics, interest rates, capital account openness.

Author's E-Mail Address: sarslanalp@,imf.org, jlee3@imf.org, urawat@,imf.org

\footnotetext{
${ }^{1}$ The research behind this paper was mostly conducted while three authors were in the Asia and Pacific Department, and the early version was presented in the IMF's 2017 Regional Economic Outlook: Asia Pacific. The authors thank, without implicating, the comments and suggestions from many colleagues including Ken Kang, Gian Maria Milesi-Ferretti, Changyong Rhee, and Ranil Salgado. The authors thank Ursula Wiriadinata and Qianqian Zhang for excellent research assistance. All errors and misinterpretations are those of the authors.
} 


\section{CONTENTS}

Abstract............................................................................................................................................

I. Introduction .............................................................................................................................................

II. Real Interest Rates and Demographic Change ...........................................................................

III. Model Specification and Results ................................................................................................10

IV. Conclusions ...................................................................................................................................20

\section{FIGURES}

1. Selected Asia: Change in 10-Year Government Yield .....................................................

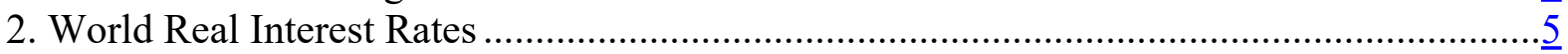

3. Selected Asia: Real Neutral Interest Rates ..................................................................... $\frac{6}{6}$

4. Asia: Fertility, Life Expectancy and Population Growth...................................................... 6

5. Asia and the Rest of the World: Change in Working-Age Population ...................................

6. Number of Years for the Old-Age Dependency to Increase from 15 to 20 Percent .............. $\frac{8}{3}$

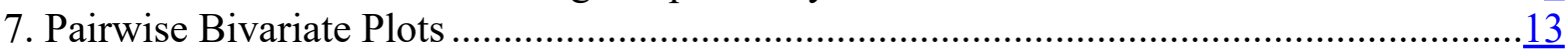

8. Selected Asia: Impact of Demographics on 10-Year Real Interest Rates ............................19

\section{TABLES}

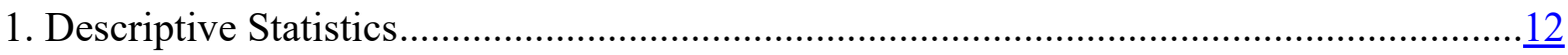

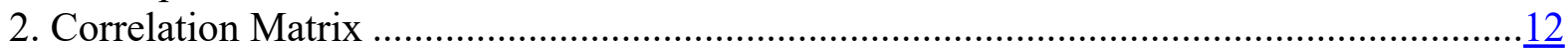

3. Panel Regression: Demographics and Long-Term Interest Rates .......................................14

4. Panel Regression: Demographics and Long-Term Interest Rates …….............................

5. Alternative Specifications: Demographics and Long-Term Interest Rates ........................ $\frac{16}{16}$

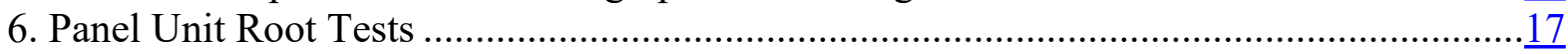

7. Long Horizon Evidence on Demographic Structure and Real Rates.................................. 18

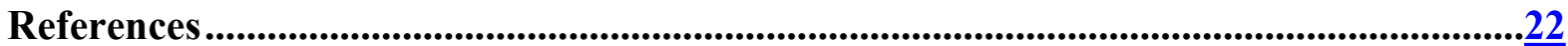




\section{INTRODUCTION}

Since the Global Financial Crisis (GFC), long-term bond yields have declined significantly in Europe and the United States. A similar trend is observed in Asia, particularly in Australia and Korea, where the decline has been nearly as large. The accommodative monetary policies (both conventional and unconventional) that were put in place in response to the GFC are an important force behind these low real rates. However, a closer look at the longer-term trend reveals that these rates have been on a decline for more than two decades across many countries, suggesting factors other than accommodative monetary policies are at play.

The growing literature on secular stagnation has identified several factors behind the observed decline in interest rate trends. Summers (2014), Eggertsson and Mehrotra (2014) and Gordon (2016) ascribe it to structural factors that have led to a persistent imbalance between demand for investment and supply of savings. These include - adverse demographic developments, a falling price of investment, lower productivity growth, savings glut, scarcity of safe assets and increasing wealth and income inequality. The GFC added further downward pressure on interest rates due to its impact on investment demand, productivity and supply of safe assets. As the global economy is moving towards recovery, the adverse effects of some of these forces is expected to decline. However, structural factors, most notably lower productivity growth and demographic developments are likely to keep real interest rates low for a long time.

In this paper, we focus on the impact of demographic trends, which due to its high persistence are likely to continue to push interest rates down in the medium term. Despite the growing interest in this topic, so far only a few papers have empirically investigated the role of demographic factors on real interest rates (Aksoy and others (2016), Favero and Galasso (2016), and Ferrero and others (2017)). Moreover, existing studies focus on either the OECD countries or the euro area. The objective of our paper is to provide new evidence on the relation between demographic trends and real interest rates over a larger sample of countries covering advanced and emerging-market economies, and explore its implications on Asian countries. Further, unlike earlier papers, we take into account the role of financial integration while assessing the impact of demographics on interest rates.

Our results indicate that demographic trends are likely to put downward pressure on real interest rates for most major countries in Asia. These direct effects are however likely to be less important for countries that are financially open. For financially open economies that are well integrated into global markets, changes in the world interest rate - which may in turn be driven by global aging trends - will likely matter more than local demographics. Globally or locally, demographic trends may lower the natural rate of interest and thereby narrow the scope for central banks to achieve price stability and maintain output at its potential. In addition, to the extent that demographic factors affect the medium-term trends in nominal and real interest rates, they may also pose risks to financial stability which calls for a strong macro-prudential framework to be put in place. 
The paper is organized as follows. Section 2 begins with a description of trends in long-term real interest rates as well as estimated natural interest rates in major Asian economies. We then look at demographic trends in Asia, present theoretical priors, and discuss empirical literature on the link between demographic variables and interest rates. Section 3 outlines the empirical model and estimation results, including forward-looking assessments based on population projections. Finally, we conclude in section 4 with policy implication for financial stability and the conduct of monetary policy.

\section{REAL INTEREST RATES AND DEMOGRAPHIC CHANGE}

Since the GFC, long term real interest rates have declined significantly, particularly in advanced economies. Asia is no exception to this declining trend. Figure 1 shows that interest rates have fallen significantly in both advanced and emerging markets in Asia. For instance, world real interest rates, which have drifted down from around 4 percent in the late-1990s to about zero by 2014 (Figure 2).

Figure 1. Selected Asia: Change in 10-Year Government Yield (Percentage points; end-2016 compared to 2000-07 average)

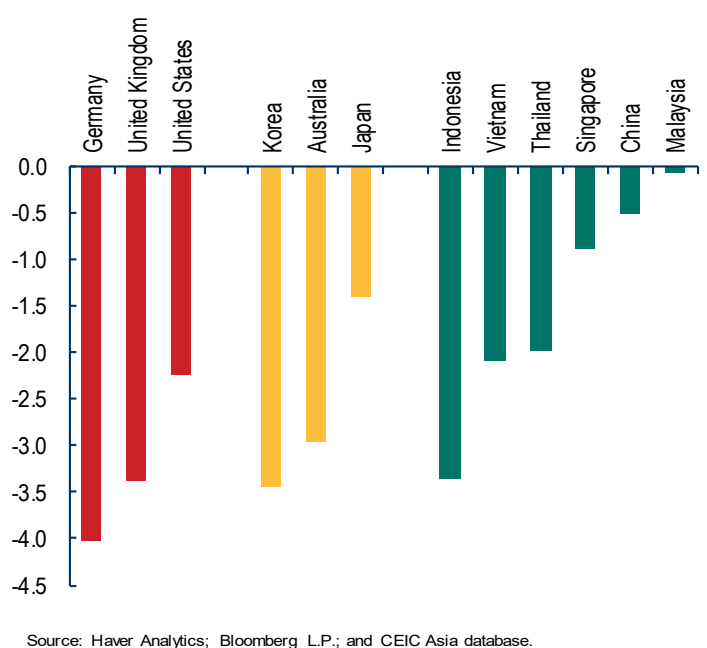

\section{Figure 2. World Real Interest Rates} (Percent)

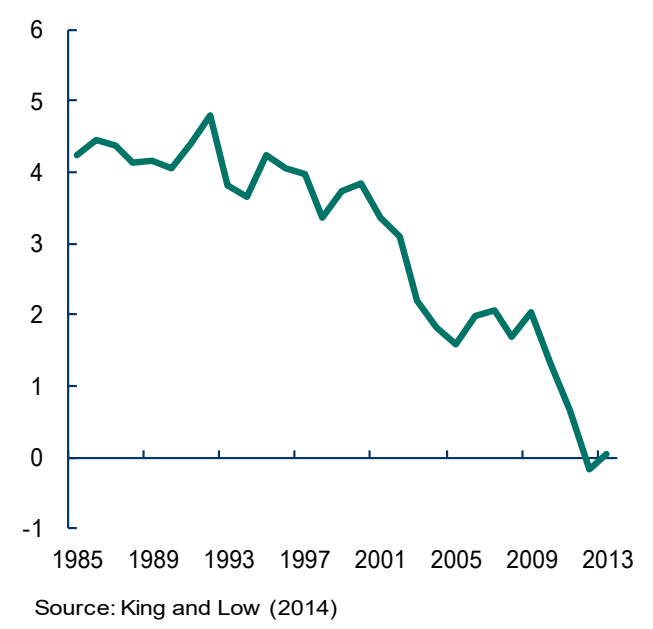


This decline in real interest rates has reflected, apart from better anchored inflation expectations, the decline in the natural rate of interest. ${ }^{2}$ Studies have shown that the estimated natural rates of interest in Europe, the United Kingdom, and the United States have declined dramatically since the start of the global financial crisis (Holston, Laubach, and Williams 2017; Lubik and Matthes 2015; Rachel and Smith 2015). In Asia, natural rates have also fallen in advanced economies (Australia, Japan, and Korea), while remaining broadly stable and relatively high in emerging economies that are yet to come under aging pressures. In China, natural rates have fallen, but remain high relative to advanced Asian economies.

\author{
Figure 3. Selected Asia: Real Neutral \\ Interest Rates \\ (Percentage points)
}

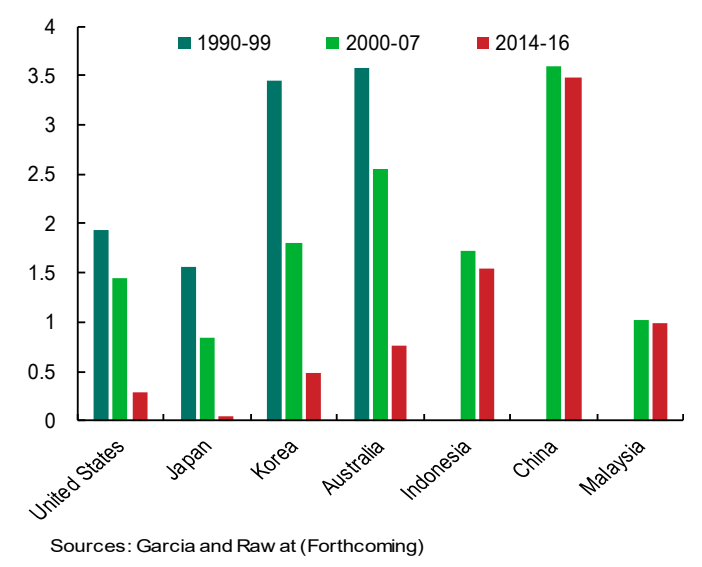

\section{A. Demographic Trends}

Demographics have been hailed as one of important drivers of the secular decline in interest rates. ${ }^{3}$ The world has been undergoing a dramatic demographic transition driven by changes in longevity and fertility. In most advanced economies people live longer and longer. In Japan, the U.S. and Western Europe, life expectancy at birth has increased by about 10 years between 1960 and 2010, and new generations have continued to expect longevity to increase. At the same time, population growth rates are decreasing at a fast pace.

Asia is also undergoing a demographic transition marked by slowing population growth and rapid aging. This mainly reflects declining fertility rates since the late 1960s and to a lesser extent rising life expectancy (Figure 4). The population growth rate, already negative in Japan, is projected to fall to zero for Asia by 2050. These trends together have led to a notable increase in the dependency

Figure 4. Asia: Fertility, Life Expectancy and Population Growth (Percent on the left scale; Year on the right scale)

\footnotetext{
2 The natural rate is the interest rate that is consistent with full employment and inflation at the central bank's target.

${ }^{3}$ Other drivers of the secular decline in natural interest rates can be a slowdown in trend productivity growth, shifts in saving and investment preferences (that is, rising inequality), precautionary savings in emerging markets, a fall in the relative price of capital goods, and a preference away from public investment (Rachel and Smith, 2015).
}

(continued...) 
ratio-i.e. the ratio between people 65 years and older and people 15 to 64 years. The share of the population age 65 and older (old-age population) will increase rapidly and reach close to $2 \frac{1}{2}$ times the current level by 2050. East Asia, in particular, is projected to be the world's fastestaging region in the coming decades, with its old-age dependency ratio roughly tripling by $2050 .{ }^{4}$

The working-age population share - the other side of dependency ratio - is at its peak now and projected to decline over coming decades. Figure 5 presents absolute changes in the working-age population for different demographic country groups in Asia and for the rest of the world. Between 1970 and 2010, Asia contributed more to the growth of the global working-age population than the rest of the world combined. This, however, is changing. Over the coming decades, rapidly aging East Asian economies are projected to see their working-age populations drop substantially. The decline is largest in absolute terms for China (a decline of 170 million in the working-age population over the next 35 years), but there are also substantial absolute declines projected for Japan, Korea, and Thailand.

\section{Figure 5. Asia and the Rest of the World: Change in Working-Age Population (Millions)}

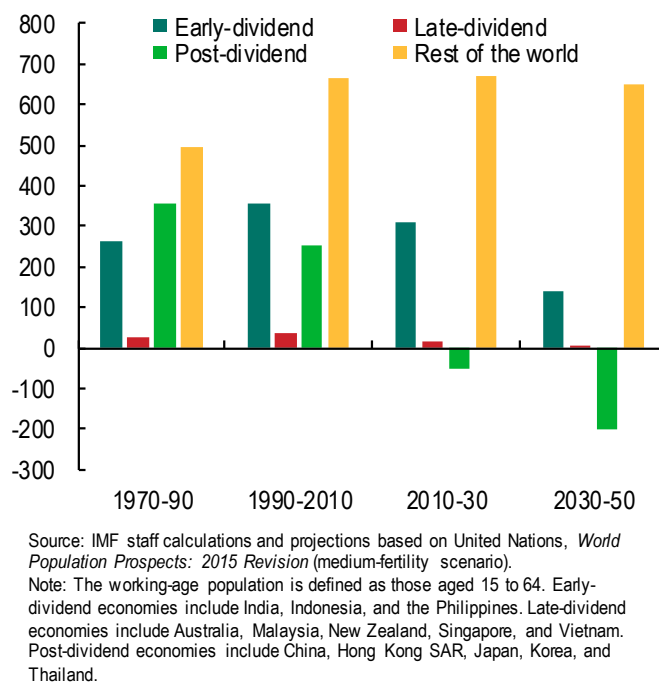

While Asia is not the most-aged region-Europe holds that distinction - the speed of aging in Asia is remarkable. Figure 6 shows the number of years it takes for the old-age dependency ratio to increase from 15 to 20 percent. The figure shows that this transition took 26 years in Europe and more than 50 years in the United States. In Asia, however, only Australia and New Zealand aged at similar speeds. For others, such as China, Japan, Korea, Thailand, Singapore, and Vietnam, the same transition has taken (or will take) less than 10 years.

\footnotetext{
${ }^{4}$ Population projections in this paper are based on United Nations, World Population Prospects: 2015 Revision (medium-fertility scenario with unchanged net migration flows).
} 
Figure 6. Number of Years for the Old-Age Dependency to Increase from 15 to 20 Percent

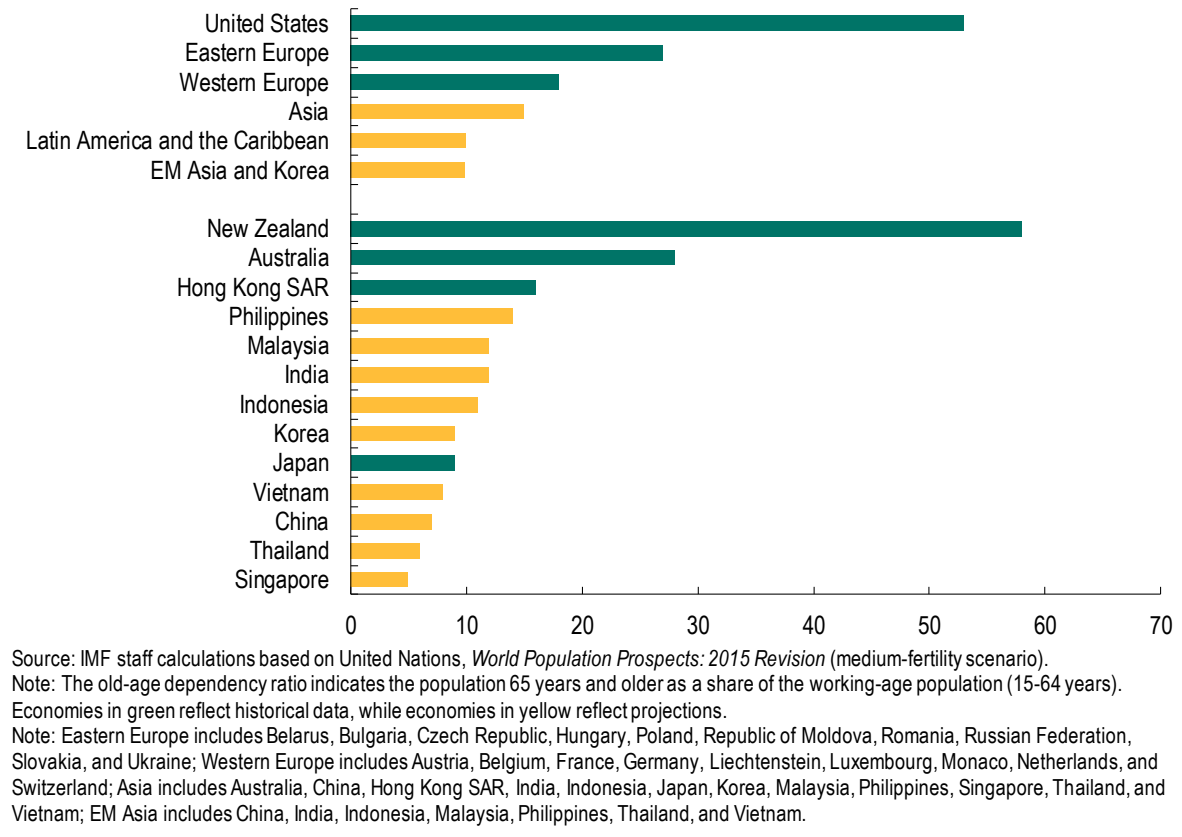

\section{B. Theoretical Priors}

Demographics constitute a key structural factor that affects economic activity including incomes, savings, and investment. Through the impact on aggregate savings and investment, demographic changes affect financial markets and interest rates.

Private saving behavior, according to the life cycle hypothesis, is age-dependent. Young households borrow against their future income, middle-age households save for relinquishing debts and retirement, and old-aged households dis-save. Accordingly, aggregate savings is more likely to fall in countries with a relative young or old population (Modigliani 1970). Other theories expand the life cycle theory to include the influence of other factors. Carroll (1997) highlights the role of uncertainty for precautionary saving. Li, Zhang and Zhang (2007) highlight the importance of longevity. Population aging is characterized not only by rising old-age dependency but also by rising longevity. As people expect to live longer, they are induced to save more, counterbalancing the impacts of higher old-age dependency. Public saving is also likely to drop with increased dependency rates. A smaller work force can result in lower tax revenues. At the same time, an increase in dependents, particularly elderly people, will increase age-related public spending (e.g. on healthcare and pension).

Investment depends positively on the return on capital, which, in turn depends on capital's relative availability. As the working-age population shrinks, capital becomes relatively abundant, and, other things equal, returns on capital should fall lowering investment. Hence, investment should fall with population aging. On the other hand, as population growth increases, the capitalto-labor ratio falls (therefore raising the return on capital and boosting investment). 
Higgins (1988) argues that the demographic "center for gravity" for investment demand should be earlier in the age distribution than that for savings supply. Such asymmetry will influence the effects of demographic changes to the balance of saving and investment, and thus on current account and interest rates. Investment demand is related positively to the share of the youth, or labor-force growth, whereas savings supply is most closely related to the share of mature adults (close to retirement ages). This implies that when the youth dependency rate rises initially, investment demand can increase, while saving declines. Then, as the age distribution shifts toward the middle age, saving increases and investment demand declines, thereby lowering interest rates. Eventually, an increase in the elderly dependency rate would cause saving to fall, surpassing investment demand decline, thereby raising interest rates.

The magnitude of the interest rate adjustment to saving and investment imbalance depends critically on the extent of the country's openness, which points to the importance of economic integration. In a closed economy, aggregate national saving and aggregate domestic investment move together. The price of funds i.e. the domestic real interest rate would then act as the equilibrating factor. For example, a fall in the saving rate would lead to a shortage of funds in the financial market, and would raise the real interest rate. In turn, the real interest rate increase would decrease investments resulting in an unchanged current account balance. In a small open economy with perfect capital mobility, a fall in saving rate would lead to deterioration of current account as the gap between domestic saving and investment is filled by an increase in net capital inflows. In all other intermediate cases (for example, a large open economy or an open economy with imperfect capital mobility), a fall in the savings rate may lead to rising real interest rate, falling investment, and worsening current account, all occurring simultaneously.

\section{Empirical Literature}

Several studies have used general equilibrium models, with various degrees of richness, to study the impact of demographic trends on asset returns (Yoo (1994), Abel (2001), Brooks (2000)). These studies confirm the theoretical insight that shocks to the rate of population growth can affect returns, while simulation results from Yoo (1994) and Brooks (2000) suggest that the effects of plausible-sized demographic shocks on returns may be quantitatively modest. There have also been several studies that use multi-region calibrated general equilibrium models to examine the effects of global demographic changes (Feroli (2003), Brooks (2003), IMF (2004)). The results generally suggest that the demographic changes projected over the next 50 years will decrease aggregate saving rates in advanced economies, particularly Europe and Japan, making these countries capital importers in long run.

More recently, Carvalho et. al. (2016) find that based on a tractable life cycle model, demographic transition has a significant lowering impact on the equilibrium interest rate. In particular, for their representative developed country, the equilibrium annual real rate falls by 1.5 percentage points between 1990 and 2014. Gagnon et al. (2016) find that a calibrated overlapping-generation model accounts for $1 \frac{1}{4}$ percentage points decline in the U.S. equilibrium real interest rate since 1980 . The model has a rich demographic structure capturing key features 
of the U.S. demographic transition, and the basic results withstand various robustness checks including on technology growth process.

There are limited econometric studies of the impact of population-age structure on interest rates. Poterba (2001) finds a robust link between age structure and long-term bond yields in the U.S. More recently in Aksoy and others (2016), the current trend of aging population and reduced fertility is found to reduce output growth and real interest rates across 21 OECD countries using a panel VAR 5 . Ferrero and others (2017) show that lower population growth exerted downward pressures on long-term real interest rates in the euro area over the past decade. Finally, Favero and Galasso (2016) expect interest rates for the euro area to revert to their historical means based on demographic-based projections.

In this paper, we examine empirically the effect of demographics on long-term real interest rates on the basis of panel data comprising advanced and major emerging market economies. Unlike other studies, we also account for the role played by capital market openness in the transmission of demographic factors to interest rates. The econometric results are applied to study the impact of projected demographic transition in Asia on the real interest rates.

\section{MODEL SPECIFICATION AND RESULTS}

In a closed economy, demographics can impact savings and thereby interest rates, primarily through youth dependency, old-age dependency, and aging speed.

- Youth dependency. In principle, as the youth dependency ratio rises, the working-age cohort saves less (to cover the rising expenditure on children), the capital-to-labor ratio falls, and interest rates rise. Youth dependency is expected to fall in early-dividend countries, such as the Philippines and India, based on the United Nations medium fertility scenario. ${ }^{6}$

- $\quad$ Old-age dependency. As old-age dependency rises, savings fall. Moreover, as the labor force shrinks, the capital-to-labor ratio rises, and investment falls. Therefore, the impact of old-age dependency on interest rates

\begin{tabular}{|l|c|c|c|}
\hline & Savings & Invesment & Interestrates \\
\hline Youn dependency & $\downarrow$ & $\uparrow$ & $\uparrow$ \\
\hline Old-age dependency & $\downarrow$ & $\downarrow$ & Ambiguous \\
\hline Aging Speed & $\uparrow$ & $\downarrow$ & $\downarrow$ \\
\hline
\end{tabular}
is theoretically uncertain. Old-age dependency is expected to rise relatively quickly in Hong Kong SAR, Korea, and Singapore.

\footnotetext{
${ }^{5}$ Aksoy and others (2016) use the short-term central bank discount rate as the relevant interest rate. Movement in short-term interest rates is however governed more by cyclical factors and less so by structural factors like demographics. In this study therefore, we focus on 10-year bond yields as the relevant interest rate variable.

${ }^{6}$ Post-dividend category includes economies where the working-age population is shrinking in terms of its share in the total population as well as in absolute numbers while in early-dividend economies, the share of the working-age population is projected to rise both as a share of the total population and in absolute terms over the next 15 years.
} 
- $\quad$ Aging speed. Aging speed is defined as the expected change in old-age dependency in 20 years. Higher aging speed implies a higher probability of survival, which, if not matched by later retirement, is likely to have a positive impact on life cycle savings. Higher aging speed also lowers current investment, as mentioned earlier, thereby reducing interest rates. Aging speed is currently high and expected to fall in countries in late stages of the demographic transition. Japan, where aging speed will continue to increase in the next decade, is an exception.

In a financially open economy, these direct effects of demographics get attenuated by global factors. In a small open economy that is fully financially integrated, its real interest rates will be driven by global interest rates, which will be little affected by the country's demographics. A large open economy's interest rate will be influenced by its own demographics, but indirectly through the effect of its demographics on global interest rates.

\section{Methodology}

Motivated by theoretical insights, three variables - youth dependency ratio, old-age dependency ratio, and aging speed - are used to capture different aspects of demographic transition and the effects on long-term interest rates. The impact of demographics on interest rates will depend also on the degrees of openness. The baseline approach involves a panel regression on dependent variable with country fixed effects. Specifically, the model takes the following form:

$$
\begin{gathered}
r_{i t}=\beta_{0}+\beta_{1} Y D_{i t}+\beta_{2}\left(Y D_{i t} * C O_{i t}\right)+\beta_{3} O D_{i t}+\beta_{4}\left(O D_{i t} * C O_{i t}\right)+\beta_{5} A S_{i t}+ \\
\beta_{6}\left(A S_{i t} * C O_{i t}\right)+\beta_{7} R W_{t}+\gamma \text { Controls }_{i t}+\varepsilon_{i t}
\end{gathered}
$$

where $i$ indicates the country and $t$ indicates the year. The dependent variable, $r$, denotes the 10year real interest rates. Among the explanatory variables, $Y D$ and $O D$ denote the youth dependency ratio (the ratio of population aged under 30 divided by population between 30 and 64 years old) and the old-age dependency ratio (the ratio of population aged over 64 divided by population between 30 and 64 years old) respectively, to account for the effects of changes in fertility and aging population on interest rates. $A S$ denotes the aging speed (as defined earlier). These variables are also separately interacted with the capital openness index $C O$ to analyze how openness of the economy effects the impact of demographic variables on interest rates.

Another explanatory variable is $R W$ that denotes the world interest rate. In an integrated world, the domestic interest rate is likely to be affected by both global and local factors. Global factors are reflected in the world interest rate, which among other things controls for the world savingsinvestment balance. The other control variables (Controls) include the ratio of a country's GDP per capita to that of the United States, growth in labor productivity, and the cyclically-adjusted primary balance. Real interest rates are driven by both cyclical and structural factors. While demographic trends are used for long-term structural factors, relative GDP per capita, labor productivity and the primary balance capture the short to medium-term drivers of interest rates. For a constant capital-to-labor ratio, an increase in labor productivity should lead to an increase in the real interest rates. The evidence on the effect of the fiscal balance on real interest rates is 
mixed, while some studies find a positive link (Engen and Hubbard (2004)), others find no effect (Barro and Sala-I Martin (1990), Barro (1992), Elmendorf and Mankiw (1999)).

\section{Data}

The data sample spans the period from 1985 to 2013 and includes 42 economies in the world. ${ }^{7}$ The 10-year real interest rates and world interest rate data come from IMF (2014), King and Low (2014), and the IMF World Economic Outlook. The demographics data come from the United Nations, the labor productivity data from Penn World Table 9.0, and the GDP and fiscal data from the IMF World Economic Outlook. The capital openness index is based on the Chinn-Ito Index (2006).

Tables 1 and 2 present descriptive statistics and pairwise correlations for the real interest rate and its determinants discussed in the paper.

Table 1. Descriptive Statistics

(Panel sample)

\begin{tabular}{lccccc} 
Variable & Obs & Mean & Std. Dev. & Min & Max \\
\hline 10-year real interest rate & 1,000 & 3.20 & 3.27 & -10.93 & 32.91 \\
Youth dependency ratio & 1,000 & 1.02 & 0.38 & 0.55 & 2.40 \\
Old dependency ratio & 1,000 & 0.28 & 0.09 & 0.11 & 0.54 \\
Aging speed & 1,000 & 0.10 & 0.08 & -0.08 & 0.36 \\
World interest rate & 1,000 & 2.75 & 1.43 & -0.17 & 4.80 \\
Chinn Ito index & 960 & 0.76 & 0.32 & 0.00 & 1.00 \\
Growth in labor productivity & 1,000 & 1.68 & 2.49 & -11.46 & 10.81 \\
Ratio of GDP per capita to that of the US & 1,000 & 0.71 & 0.46 & 0.01 & 2.47 \\
Cyclically adjusted primary balance & 765 & -0.14 & 3.45 & -15.09 & 11.34 \\
\hline
\end{tabular}

Source: Authors' calculations.

Table 2. Correlation Matrix

\begin{tabular}{|c|c|c|c|c|c|c|c|c|c|}
\hline & $\begin{array}{l}10 \text {-year real } \\
\text { interest rate }\end{array}$ & $\begin{array}{c}\text { Youth } \\
\text { dependency } \\
\text { ratio }\end{array}$ & $\begin{array}{c}\text { Old } \\
\text { dependency } \\
\text { ratio } \\
\end{array}$ & Aging speed & $\begin{array}{c}\text { World interest } \\
\text { rate }\end{array}$ & $\begin{array}{l}\text { Chinn Ito } \\
\text { index }\end{array}$ & $\begin{array}{l}\text { Growth in } \\
\text { labor } \\
\text { productivity }\end{array}$ & $\begin{array}{l}\text { Ratio of GDP } \\
\text { per capita to } \\
\text { that of the US }\end{array}$ & $\begin{array}{l}\text { Cyclically } \\
\text { adjusted } \\
\text { primary }\end{array}$ \\
\hline 10-year real interest rate & 1.00 & & & & & & & & \\
\hline Youth dependency ratio & 0.21 & 1.00 & & & & & & & \\
\hline Old dependency ratio & -0.04 & -0.74 & 1.00 & & & & & & \\
\hline Aging speed & -0.38 & -0.57 & 0.19 & 1.00 & & & & & \\
\hline World interest rate & 0.42 & 0.06 & 0.07 & -0.53 & 1.00 & & & & \\
\hline Chinn Ito index & -0.14 & -0.60 & 0.57 & 0.39 & 0.01 & 1.00 & & & \\
\hline Growth in labor productivity & 0.05 & 0.22 & -0.30 & -0.17 & 0.11 & -0.25 & 1.00 & & \\
\hline Ratio of GDP per capita to that of the US & 0.09 & -0.52 & 0.60 & 0.08 & 0.16 & 0.49 & -0.24 & 1.00 & \\
\hline Cyclically adjusted primary balance & 0.07 & 0.08 & -0.24 & 0.02 & 0.09 & 0.03 & 0.01 & -0.27 & 1.00 \\
\hline
\end{tabular}

Source: Authors' calculations.

\footnotetext{
${ }^{7}$ The economies include Argentina, Australia, Austria, Belgium, Brazil, Canada, Chile, China, Colombia, Czech Republic, Denmark, Finland, France, Germany, Greece, Hong Kong SAR, Iceland, India, Indonesia, Ireland, Israel, Italy, Japan, Korea, Malaysia, Mexico, Netherlands, New Zealand, Norway, Peru, Philippines, Portugal, Romania, Singapore, South Africa, Spain, Sweden, Switzerland, Thailand, Ukraine, United Kingdom, and United States.
} 
Figure 7. Pairwise Bivariate Plots
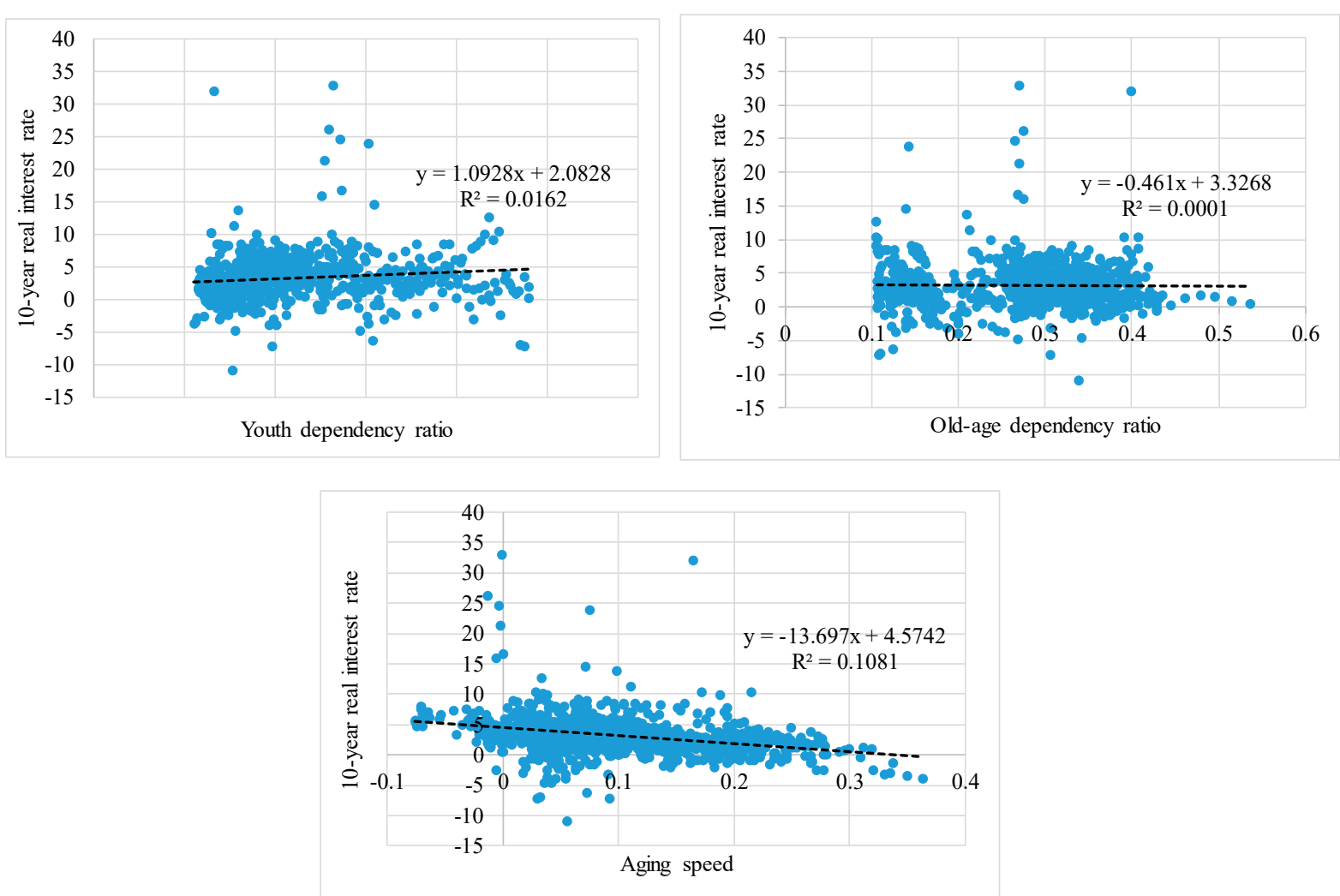

Bivariate plots of the real interest rate and demographic variables show a positive relationship between youth dependency ratio and the 10-year real interest rate and a negative relationship between the other two demographic variables — old-age dependency and aging speed — with the 10 -year interest rate.

\section{Results}

The baseline results (Table 3) support our priors for the effect of youth dependency and aging speed on real interest rates. An increase in youth dependency tends to increase interest rate while higher aging speed reduces it. Furthermore, we find that for our sample, an increase in olddependency leads to a fall in interest rates. This implies that the investment channel dominates the savings channel.

The effects of demographic factors are not wholly channeled domestically in open economies. As one moves to an economy with an open capital account, the savings-investment balance, and hence interest rates, are at least partly determined by global savings and investment. In the extreme case of perfect capital mobility, arbitrage in financial markets should equalize interest rates across borders, and demographic factors of each country should not have a direct impact on domestic interest rates (unless they are large enough to contribute to global demographic trends). 
This is reflected by the opposite signs on our variables of interest when they are interacted with capital openness.

Table 3. Panel Regression: Demographics and Long-Term Interest Rates

\begin{tabular}{lc} 
Dependent variables & 10-year real interest rate \\
\hline & $9.41^{* * *}$ \\
Youth dependency ratio & $(2.36)$ \\
& $-7.96^{* * *}$ \\
Youth dependency ratio * capital openness & $(2.26)$ \\
& $-18.30^{* * *}$ \\
Old-age dependency ratio & $(4.97)$ \\
& $17.04^{* * *}$ \\
Old-age dependency ratio * capital openness & $(5.32)$ \\
& $-29.70^{* *}$ \\
Aging speed & $(13.94)$ \\
& $25.89^{* *}$ \\
Aging speed * capital openness & $(12.29)$ \\
& $0.65^{* * *}$ \\
World interest rate & $(0.12)$ \\
& 2.38 \\
Ratio of GDP per capita to that of the US & $(1.48)$ \\
& -0.00 \\
Cyclically adjusted primary balance & $(0.06)$ \\
& 0.07 \\
Growth in labor productivity & $(0.08)$ \\
& \\
Observations & 740 \\
Number of groups & 42 \\
\hline
\end{tabular}

Source: IMF staff estimates.

Note: Standard errors in parentheses. The symbols *, $* *, * * *$ indicate statistical significance at the 10 percent, 5 percent, and 1 percent levels, respectively.

To further assess how capital mobility affects the impact of demographics on domestic interest rate, we test the following restrictions $\beta_{1}=-\beta_{2}, \beta_{3}=-\beta_{4}$, and $\beta_{5}=-\beta_{6}$. With the $\mathrm{F}$ tests showing that we cannot reject these null hypotheses (Annex Table 1), we run an alternative specification that takes the following form where notations are the same as above:

$$
\begin{aligned}
r_{i t}= & \alpha_{0}+\alpha_{1} Y D_{i t} *\left(1-C O_{i t}\right)+\alpha_{2} O D_{i t} *\left(1-C O_{i t}\right)+\alpha_{3} A S_{i t} *\left(1-C O_{i t}\right)+\alpha_{4} R W_{t}+ \\
& \mu \text { Controls } s_{i t}+\varepsilon_{i t}
\end{aligned}
$$


Table 4. Panel Regression: Demographics and Long-Term Interest Rates

\begin{tabular}{lc} 
Dependent variables & 10-year real interest rate \\
\hline & $8.26^{* * *}$ \\
Youth dependency ratio*(1 - capital openness) & $(2.20)$ \\
& $-16.16^{* * *}$ \\
Old-age dependency ratio*(1 - capital openness) & $(4.59)$ \\
& $-29.26^{* *}$ \\
Aging speed*(1 - capital openness) & $(12.67)$ \\
& $0.84^{* * *}$ \\
World interest rate & $(0.10)$ \\
& 2.43 \\
Ratio of GDP per capita to that of the US & $(1.51)$ \\
& 0.00 \\
Cyclically adjusted primary balance & $(0.06)$ \\
& 0.07 \\
Growth in labor productivity & $(0.08)$ \\
& \\
Observations & 740 \\
Number of groups & 42 \\
\hline Source: IMF staff estimates. & \\
Note: Standard errors in parentheses. The symbols * ***** $*$ indicate statistical \\
significance at the 10 percent, 5 percent, and 1 percent levels, respectively.
\end{tabular}

Our results indicate that domestic real interest rate strongly co-moves with the world interest rate. A one percentage point increase in the world interest rate would increase the domestic interest rate (in a small open economy) by 0.8 percentage point. Demographic variables are also strongly significant. In particular, in a fully open economy i.e. capital openness equal to one, domestic demographic changes do not have any impact on real interest rate. However, in a fully closed economy a 1 percentage point increase in youth dependency increases the interest rate by 8.26 basis points. Similarly, a 1 percentage point increase in old-age dependency and aging speed reduces interest rate by 16 and 29 basis points, respectively.

We further check our baseline results by estimating the following alternative specifications (i) using the U.S. real interest rate instead of the world interest rate; and (ii) using time dummies to control for global factors. These results are presented in table 5. The impact of demographic variables on the real interest rate is largely robust to these refinements. Column (1) shows the baseline results while in column (2) the world interest rate is replaced by U.S, real interest rate. Therefore, we drop the U.S. from our sample when estimating this specification. The results are largely similar reflecting the dominant role played by the U.S. in the world financial system. In column (3), we introduce year fixed effects to account for country invariant global factors. The results on demographic variables are again mostly robust with an exception of aging speed. While aging speed continues to have similar qualitative effects, it is found to be less significant. Finally, in column (4) we add both the world interest rate as well as year effects. The impact of demographic variables on interest rates is unchanged (between column (3) and (4)), however the coefficients on year dummies (not reported) changes. This implies that both the world interest rate and the time dummies together account for global factors in this specification. The other 
control variables come with coefficients that are not statistically significant, albeit in signs consistent with theoretical priors.

Table 5. Alternative Specifications: Demographics and Long-Term Interest Rates

\begin{tabular}{lcccc} 
VARIABLES & $(1)$ & $(2)$ & $(3)$ & $(4)$ \\
\hline & & & & \\
Youth dependency ratio & $9.41^{* * *}$ & $8.86^{* * *}$ & $6.62^{* * *}$ & $6.62^{* * *}$ \\
& $(2.36)$ & $(1.93)$ & $(1.89)$ & $(1.89)$ \\
Youth dependency ratio * capital openness & $-7.96^{* * *}$ & $-7.38^{* * *}$ & $-9.98^{* * *}$ & $-9.98^{* * *}$ \\
& $(2.26)$ & $(2.16)$ & $(2.17)$ & $(2.18)$ \\
Old-age dependency ratio & $-18.30^{* * *}$ & $-21.84^{* * *}$ & $-23.13^{* *}$ & $-23.13^{* *}$ \\
& $(4.97)$ & $(5.55)$ & $(9.97)$ & $(9.98)$ \\
Old-age dependency ratio * capital openness & $17.04^{* * *}$ & $16.82^{* * *}$ & $30.87^{* * *}$ & $30.87^{* * *}$ \\
& $(5.32)$ & $(5.49)$ & $(9.23)$ & $(9.23)$ \\
Aging speed & $-29.70^{* *}$ & $-32.26^{* *}$ & -16.66 & -16.66 \\
& $(13.94)$ & $(14.62)$ & $(15.14)$ & $(15.15)$ \\
Aging speed * capital openness & $25.89^{* *}$ & $25.64^{*}$ & $27.37^{*}$ & $27.37^{*}$ \\
& $(12.29)$ & $(12.72)$ & $(14.46)$ & $(14.47)$ \\
World interest rate & $0.65^{* * *}$ & & & $1.95^{* * *}$ \\
& $(0.12)$ & & & $(0.31)$ \\
Ratio of GDP per capita to that of the US & 2.38 & $2.53^{*}$ & 1.44 & 1.44 \\
& $(1.48)$ & $(1.38)$ & $(1.97)$ & $(1.97)$ \\
Cyclically adjusted primary balance & -0.00 & 0.02 & 0.03 & 0.03 \\
& $(0.06)$ & $(0.05)$ & $(0.06)$ & $(0.06)$ \\
Growth in labor productivity & 0.07 & -0.01 & -0.01 & -0.01 \\
& $(0.08)$ & $(0.06)$ & $(0.06)$ & $(0.06)$ \\
US real interest rate & & $0.54^{* * *}$ & & \\
& & $(0.10)$ & & \\
Observations & & & & \\
Number of groups & & & & \\
Country fixed effects & & & & \\
Time fixed effects & & & & \\
\hline
\end{tabular}

Source: IMF staff estimates.

Note: Standard errors in parentheses. The symbols *,**,*** indicate statistical significance at the 10 percent, 5 percent, and 1 percent levels, respectively.

\section{Robustness}

Econometric analyses presented above should be viewed with caution, because the explanatory demographic variables evolve slowly. To account for this, we formally test for the presence of a unit root (with constant and trend) in demographics-related variables and can reject the null of unit root in only one case. 
Table 6. Panel Unit Root Tests

\begin{tabular}{|c|c|c|c|c|c|}
\hline \multicolumn{6}{|c|}{ Null: Non-stationarity (of order 1) } \\
\hline \multirow[t]{2}{*}{ Variable } & \multirow[t]{2}{*}{ Deterministic } & \multicolumn{2}{|c|}{ Fisher (modified inverse chi square test) } & \multirow[t]{2}{*}{$\begin{array}{l}\text { Im, Pesaran, } \\
\text { Shin (t-value) }\end{array}$} & \multirow[t]{2}{*}{ Result } \\
\hline & & Dickey Fuller & Phillips Perron & & \\
\hline \multirow[t]{2}{*}{ Real interest rate } & Constant & $\begin{array}{c}3.23 \\
(0.00)\end{array}$ & $\begin{array}{c}4.77 \\
(0.00)\end{array}$ & $\begin{array}{c}-1.34 \\
(0.09)\end{array}$ & $\mathbf{I}(\mathbf{0})$ \\
\hline & Trend & $\begin{array}{l}12.44 \\
(0.00)\end{array}$ & $\begin{array}{l}26.46 \\
(0.00)\end{array}$ & $\begin{array}{l}-6.03 \\
(0.00)\end{array}$ & $\mathbf{I}(\mathbf{0})$ \\
\hline \multirow[t]{2}{*}{ Youth dependency } & Constant & $\begin{array}{l}15.27 \\
(0.00)\end{array}$ & $\begin{array}{l}64.74 \\
(0.00)\end{array}$ & $\begin{array}{c}4.32 \\
(0.00)\end{array}$ & $\mathbf{I}(\mathbf{0})$ \\
\hline & Trend & $\begin{array}{c}8.25 \\
(0.00)\end{array}$ & $\begin{array}{l}10.00 \\
(0.00)\end{array}$ & $\begin{array}{c}0.26 \\
(0.60)\end{array}$ & Inconclusive \\
\hline \multirow[t]{2}{*}{ Old dependency } & Constant & $\begin{array}{c}5.90 \\
(0.00)\end{array}$ & $\begin{array}{l}-4.54 \\
(1.00)\end{array}$ & $\begin{array}{c}4.32 \\
(1.00)\end{array}$ & $\mathbf{I}(\mathbf{1})$ \\
\hline & Trend & $\begin{array}{l}11.56 \\
(0.00)\end{array}$ & $\begin{array}{l}-2.30 \\
(0.99)\end{array}$ & $\begin{array}{c}0.01 \\
(0.50)\end{array}$ & $\mathbf{I}(1)$ \\
\hline \multirow[t]{2}{*}{ Aging speed } & Constant & $\begin{array}{l}16.58 \\
(0.00)\end{array}$ & $\begin{array}{l}-2.99 \\
(0.99)\end{array}$ & $\begin{array}{l}-1.87 \\
(0.03)\end{array}$ & $\mathbf{I}(\mathbf{1})$ \\
\hline & Trend & $\begin{array}{c}6.58 \\
(0.00)\end{array}$ & $\begin{array}{l}-1.04 \\
(0.85)\end{array}$ & $\begin{array}{c}1.11 \\
(0.87)\end{array}$ & $\mathbf{I}(\mathbf{1})$ \\
\hline \multirow[t]{2}{*}{ World interest rate } & Constant & $\begin{array}{r}-6.00 \\
(1.00)\end{array}$ & $\begin{array}{l}-5.95 \\
(1.00)\end{array}$ & $\begin{array}{l}10.61 \\
(1.00)\end{array}$ & $\mathbf{I}(1)$ \\
\hline & Trend & $\begin{array}{l}-2.66 \\
(0.99)\end{array}$ & $\begin{array}{l}-2.46 \\
(0.99)\end{array}$ & $\begin{array}{c}0.92 \\
-0.82\end{array}$ & $\mathbf{I}(1)$ \\
\hline Residuals & & $\begin{array}{r}17.80 \\
(0.00) \\
\end{array}$ & $\begin{array}{r}14.82 \\
(0.00) \\
\end{array}$ & $\begin{array}{l}-7.14 \\
(0.00)\end{array}$ & $\mathbf{I}(\mathbf{0})$ \\
\hline
\end{tabular}

When the explanatory variables have unit roots, there is a risk of a spurious regression problem resulting in incorrect statistical inferences. To evaluate the potential importance of this problem, the residuals from the baseline equation are tested for the presence of a unit root. If the null hypothesis of a unit root in the residuals cannot be rejected, then the underlying regression model maybe mis-specified. Table 6 reports test statistics for the residuals based on the Fisher test as well as the Im, Pesaran and Shin test, which reject the null hypothesis of unit root.

Finally, given the low-frequency variation in demographic variables, annual real interest rates may introduce substantial noise to any relationship with a demographic structure. Therefore, three and five-year returns for non-overlapping periods are constructed (as in Poterba (2001)). Such multi-period returns are expected to emphasize the low-frequency variation in interest rates. The results (table 7) from these non-overlapping panels are similar to the baseline specification. 
Table 7. Long Horizon Evidence on Demographic Structure and Real Rates

\begin{tabular}{lccc} 
Variables & Annual model & 3-year averages & 5-year averages \\
\hline & & & \\
Youth dependency ratio & $9.41^{* * *}$ & $10.17^{* *}$ & $8.08^{* *}$ \\
& $(2.36)$ & $(3.53)$ & $(2.15)$ \\
Youth dependency ratio * capital openness & $-7.96^{* * *}$ & $-8.42^{* * *}$ & $-6.13^{* * *}$ \\
& $(2.26)$ & $(1.88)$ & $(1.39)$ \\
Old-age dependency ratio & $-18.30^{* * *}$ & $-21.45^{* * *}$ & $-13.69^{*}$ \\
& $(4.97)$ & $(5.77)$ & $(6.00)$ \\
Old-age dependency ratio * capital openness & $17.04^{* * *}$ & $20.25^{* * *}$ & $15.38^{* *}$ \\
& $(5.32)$ & $(3.56)$ & $(4.28)$ \\
Aging speed & $-29.70^{* *}$ & -23.02 & -32.42 \\
& $(13.94)$ & $(16.62)$ & $(17.82)$ \\
Aging speed * capital openness & $25.89^{* *}$ & 18.11 & 24.68 \\
& $(12.29)$ & $(14.65)$ & $(12.49)$ \\
World interest rate & $0.65^{* * *}$ & $0.64^{* * *}$ & 0.49 \\
& $(0.12)$ & $(0.19)$ & $(0.29)$ \\
Ratio of GDP per capita to that of the US & 2.38 & 2.01 & 1.74 \\
& $(1.48)$ & $(1.14)$ & $(2.00)$ \\
Cyclically adjusted primary balance & -0.00 & -0.05 & 0.06 \\
Growth in labor productivity & $(0.06)$ & $(0.08)$ & $(0.08)$ \\
& 0.07 & -0.00 & -0.09 \\
Observations & $(0.08)$ & $(0.15)$ & $(0.11)$ \\
Number of groups & & & 166 \\
Source: IMF staff estimates. & 740 & 271 & 41 \\
\hline
\end{tabular}

\section{Demographics and Interest Rates in Asia}

Next, we look at the expected evolution of real interest rates in Asian countries based on demographic projections from UN population division (2015). Our results indicate that the interest rates in Japan, Hong Kong SAR, New Zealand, and Singapore with full capital mobility are decoupled from their domestic demographic trends.

Among countries that are not perfectly open, the relative importance of different channels is based on the demographic profile of a country. The old-age dependency effect is more important for mature economies, while the youth dependency effect dominates for economies that are relatively young. Increasing old-age dependency is expected to decrease interest rates, with the effect most prominent for demographically-mature countries such as China, Korea, and Thailand. Declining youth dependency, especially in relatively young countries such as India, Indonesia, and the Philippines whose fertility rates are projected to decline, is expected to decrease interest rates (Figure 8). 
Figure 8. Selected Asia: Impact of Demographics on 10-Year

Real Interest Rates

(Percentage points; cumulative change between 2020 and 2030)

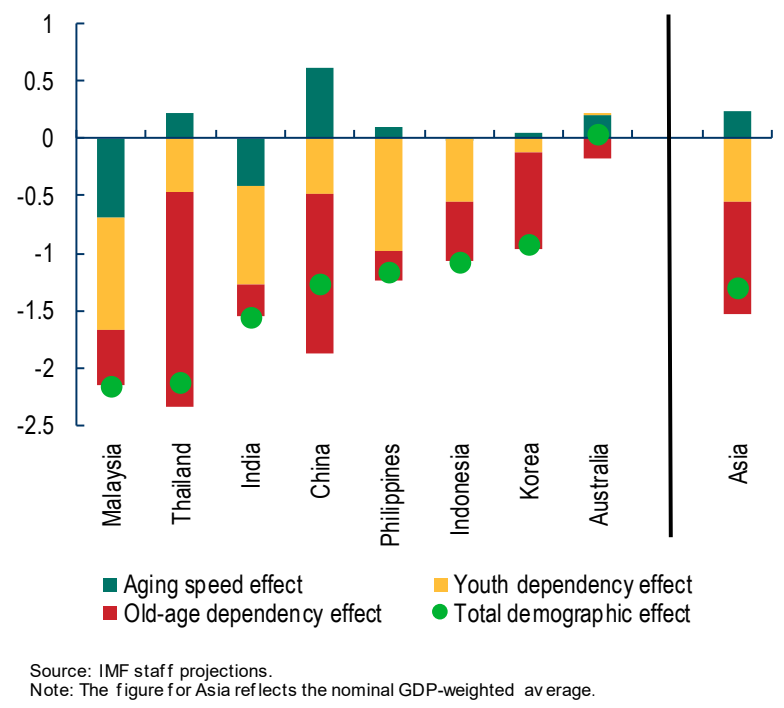

Finally, a slower pace of aging can be expected to push up interest rates. Between 2020-30, interest rates are expected to increase most markedly in China and Australia as the aging speeds in these countries fall. Given that these economies are already relatively aged, their aging speeds slow and result in a fall in savings and, consequently, an increase in interest rates. On the other hand, aging speed is projected to increase in currently young countries such as India and Malaysia, driving down their interest rates.

Overall, the results suggest that demographic trends could put downward pressure on interest rates by about 1 to 2 percentage points in the next decade, all else being equal (Figure 8$).{ }^{8}$ The impact depends on three factors: the degree of openness, the state of aging, and the speed of aging. For countries that are fully open, demographic factors do not have a direct effect on domestic long-term interest rates. For post-dividend countries (Korea and Thailand), rising oldage dependency is expected to depress interest rates. For early-dividend countries (India and the Philippines), falling youth dependency is projected to reduce interest rates. Finally, as the speed of aging slows in some cases, the aging speed effect will attenuate the decline in interest rates.

\footnotetext{
${ }^{8}$ Rachel and Smith (2015) find that demographic factors along with public investment and a global savings glut can explain about 2 percentage points (out of 4.5 percentage points) of the decline in global neutral rates between 1980 and 2015.
} 


\section{Conclusions}

The Great Recession, accompanied by slow growth, lackluster investment and high unemployment, has rekindled interest in the notion of secular stagnation. One core problem of secular stagnation is that the natural rate of interest falls too low. Relatedly, nominal and real interest rates across major advanced economies have indeed been on a secular decline for the past few decades. This trend was further accentuated by accommodative monetary policy following the GFC. As global recovery is underway, monetary policies in major advanced economies will likely normalize. However, the observed decline in world real interest rates started decades before the GFC, pointing to the importance of other structural factors.

The literature on secular stagnation has put forward several hypotheses to explain the observed decline in interest rates. An important structural factor has been adverse demographic trends, which have been examined in this paper. Our results indicate that demographic trends are likely to continue to put downward pressure on interest rates in the coming decades. Adverse demographic trends, by reducing long-term interest rates, have an impact on both the conduct and transmission of the monetary policy as well as on financial stability. For the former, the ability of a central bank to successfully attain its objective of price stability and keep output at its potential becomes more limited in an environment of low and declining natural rates of interest. This effectively squeezes their monetary policy space. The latter issue of financial stability is also closely related to a low interest rate environment which could result in elevated valuations, asset price bubbles, higher risk-taking, and a search for yield.

However, the impact of demographic variables is not wholly channeled domestically in open economies. As one moves to an economy with an open capital account, the savings-investment balance, and hence interest rates, are at least partly determined by global savings and investment. We find that the impact of domestic demographic factors on interest rates tend to diminish as a country becomes more open. In our analysis, the impact of demographic variables-youth dependency, old-age dependency, and aging speed — all become zero as an economy becomes perfectly open in its capital account. Hence, interest rates in Japan, Hong Kong SAR, New Zealand, and Singapore with full capital mobility are decoupled from their domestic demographic trends. Among countries that are not perfectly open, the old-age dependency effect is important for mature economies while the youth dependency effect dominates for economies that are relatively young. Overall, our results suggest that demographic trends in Asian economies can put downward pressure on interest rates by about 1-2 percentage points in the next decade, all else equal. 
Annex I. Table 1. F Tests: Demographics and Interaction Variables

F tests

(1) youth dependency ratio + youth dependency ratio $*$ capital openness index $=0$

$\mathrm{F}(1,28)=1.00$

Prob $>F=0.3257$

(2) old dependency ratio + old dependency ratio $*$ capital openness index $=0$

$\mathrm{F}(1,28)=0.18$

Prob $>F=0.6747$

(3) aging speed + aging speed $*$ capital openness index $=0$

$\mathrm{F}(1,28)=2.05$

Prob $>\mathrm{F}=0.1630$ 


\section{References}

Abel A.B. 2001. "Will Bequests Attenuate the Predicted Meltdown in Stock Prices When Baby Boomers Retire?", Review of Economics and Statistics, 83(4), pp 589-595.

Aksoy, Y., Basso, H., Smith, R., and T. Grasl. 2016. "Demographic structure and macroeconomic trends.” CEFifo Working Paper No. 5872.

Brooks. R. 2000. "What Will Happen To Financial Markets When the Baby Boomers Retire". Computing in Economics and Finance 2000 92, Society for Computational Economics.

Brooks. R. 2003. "Population Aging and Global Capital Flows in a Parallel Universe". IMF Staff Papers, 50(2), pp 200-221.

Carroll, C. D., and A. A. Samwick. 1997. "The Nature of Precautionary Wealth.” Journal of Monetary Economics, 40(1), pp. 41-71.

Carvalho, C., Ferrero, A., and Nechio, F. 2016. "Demographics and real interest rates: Inspecting the mechanism." European Economic Review, 88:208-226.

Eggertsson, G. and N. Mehrotra. 2014. "A model of secular stagnation.” NBER Working Paper No.20547.

Favero, C. and V. Galasso. 2016. "Demographics and the secular stagnation hypothesis in Europe.” In: After the crisis: Reform, recovery, and growth in Europe.

Ferrero, G., M. Gross, and S. Neri. 2017, “On Secular Stagnation and Low Interest Rates: Demography Matters,” ECB Working Paper No. 2088.

Gagnon, E., Johannsen, B., and D. Lopez-Salido. 2016. "Understanding the new normal: The role of demographics.” FEDS Working Paper No. 2016-080.

Gordon, R. 2016. "The rise and fall of American growth: The U.S. standard of living since the Civil War.” Princeton University Press.

Higgins, M. 1998. "Demography, National Savings, and International Capital Flows." International Economic Review 39(2): 343-69.

Holston, K., Laubach, T., and J.Williams. 2017. "Measuring the natural rate of interest: International trends and determinants." Journal of International Economics.

International Monetary Fund. 2004. "How will Demographic Change Affect the Global Economy." World Economic Outlook, Ch. 3.

International Monetary Fund. 2014. "Perspectives on global real interest rates." World Economic Outlook, Ch. 3. 
Li, H., J. Zhang, and J. Zhang. 2007. "Effects of Longevity and Dependency Rates on Saving and Growth: Evidence from a Panel of Cross Countries." Journal of Development Economics 84: $138-54$.

Lubik, T., and C. Matthes. 2015. "Calculating the Natural Rate of Interest: A Comparison of Two Alternative Approaches.” Economic Brief EB15-10. Federal Reserve Bank of Richmond.

Mapa, D. S. 2015. Demographic Sweet Spot and Dividend in the Philippines: The Window of Opportunity is Closing Fast. Manila: United Nations Population; National Economic and Development Authority.

Poterba, J.M. 2001. "Demographic Structure and Asset Returns." Review of Economics and Statistics, 83, 565-584.

Rachel, L. and T. Smith. 2015. "Secular drivers of the global real interest rate." Bank of England Staff Working Paper No. 571.

Summers, L. 2014. "U.S. economic prospects: Secular stagnation, hysteresis, and the zero lower bound." Business Economics, 49(2):65-73.

Yoo P.S. 1994. “Age Dependent Portfolio Selection”. Federal Reserve Bank of St. Louis Working Paper No 94-003A

Engen, E.M., and R.G. Hubbard. 2004. "Federal Government Debt and Interest Rates", in NBER Macroeconomics Annual 2004, Vol. 19.

Barro, Robert J. 1992. "World interest rates and investment." Scandinavian Journal of Economics 34(2):323-342.

Barro, R.J., and X. Sala-i-Martin. 1990. "World Real Interest Rates.” NBER Chapters, in: NBER Macroeconomics Annual 1990, Vol. 5, pp 15-74.

Elmendorf, D.W. and N.G. Mankiw. 1999. "Government Debt. Handbook of Macroeconomics", in: J.B. Taylor and M. Woodford (ed.), Handbook of Macroeconomics, edition 1, vol. 1, chapter 25, pp 1615-1669 Elsevier. 